Syntax Fusion : Jurnal Nasional Indonesia

p-ISSN: -

e-ISSN : 2775-4440

Vol. 1, No. 8, Agustus 2021

\title{
DAMPAK COVID-19 TERHADAP USAHA MIKRO KECIL MENENGAH (UMKM) DI DAERAH SUKAMELANG SUBANG JAWA BARAT
}

\author{
Hidzani Asti Rahyuni N dan Izzudin Fuad \\ Universitas Islam Negeri Sunan Gunung Djati Bandung \\ Email : hidzaniastirahyuni@gmail.com, izzudinfuad24@gmail.com
}

\begin{abstract}
Abstrak
Covid-19 merupakan virus yang akhir-akhir ini sedang dihadapi oleh berbagai Negara termasuk Indonesia. Bahkan Indonesia menjadi salah satu Negara yang terkena dampak cukup besar dari penyebaran covid-19 ini. Belum lagi dengan munculnya varian baru yaitu Covid-19 varian Delta, yang menyebabkan pemerintah semakin tidak bisa tinggal diam. Berbagai kebijakan telah dilakukan untuk mengurangi dampak dari virus ini. Mulai dari Lock Down, Pembatasan Sosial Berskala Besar (PSBB), Pembatasan Sosial Berskala Mikro, sampai pada Pemberlakuan Pembatasan Kegiatan Masyarakat (PPKM Jawa Bali) yang saat ini sedang dilakukan. Covid-19 ini bukan hanya berpengaruh pada kesehatan saja melainkan pada sektor ekonomi. Terutama kondisi Perekonomian masyarakat menengah kebawah. Maka dari itu penelitian kali ini akan mengkaji dampak covid19 terhadap kondisi perekonomian UMKM di daerah Sukamelang Subang Jawa Barat. Proses Pengumpulan data dilakukan dengan cara wawancara kepada beberapa pedagang yang berjualan disekitar daerah Sukamelang dan dokumentasi kemudian melakukan pendekatan penelitian metode deskriptif kualitatif. Adapun hasil penelitian ini menunjukan adanya dampak yang signifikan dari pandemi covid19 terhadap UMKM.
\end{abstract}

Kata Kunci : Covid-19, UMKM, Pedagang

\section{Pendahuluan}

Covid-19 (Coronavirus disease 2019) adalah jenis penyakit yang disebabkan oleh virus dari golongan coronavirus, yaitu SARS-CoV-2. Pertama kali terjadi kasus covid-19 ini yaitu di kota Wuhan, Cina. Kemudian virus ini menular dengan sangat cepat dan menyebar ke beerbagai Negara termasuk Indonesia. Penyebaran ini terjadi begitu cepat tidak membutuhkan waktu lama hanya dalam hitungan bulan virus ini dapat menyebar ke berbagai Negara. Menurut data yang dirilis langsung oleh Gugus Tugas Percepatan Penanganan 
Covid-19 Republik Indonesia jumlah kasus yang terkonfirmasi positif hingga 23 Juli 2021 adalah 3.033.339 orang dengan jumlah kematian 79.032 orang. Pada akhir tahun 2020 beberapa laporan menyebutkan bahwa coronavirus telah bermutasi menjadi beberapa jenis, mulai dari varian Alfa, varian Beta, varian Gamma, Varian Delta.dll.

Dari berbagai kasus Covid-19 ini ternyata bukan hanya berdampak pada krisis kesehatan saja melainkan berdampak juga pada perekonomian masyarakat. Covid-19 ini telah berhasil menimbulkan kegelisahan para pelaku ekonomi. Sebuah penelitian menyebutkan bahwa pada tahun 2020 covid-19 telah berhasil menurunkan persentase perekonomian sebesar 0,1\%. Organisation for Economic Co-operation and Development (OECD) Melaporkan bahwa pandemi ini akan berpengaruh pada ancaman krisis ekonomi yang cukup besar ditandai dengan berhentinya aktivitas produksi diberbagai Negara, jatuhnya tingkat konsumsi masyarakat, hilangnya kepercayaan konsumen, jatuhnya bursa saham yang pada akhirnya mengarah pada ketidak pastian. Sedangkan Ekonomi meerupakan salah satu faktor penting dalam kehidupan, sebagaimana diketahui bahwa seseorang akan bersinggungan secara langsung dengan kegiatan ekonomi. (Hanoatubun, 2020).

Dampak dari pandemi covid-19 ini sangat dirasakan oleh beberapa sector ekonomi termasuk UMKM. Berbagai upaya telah dilakukan oleh pemerintah sampai saat ini diberlakukan PPKM, namun niat baik pemerintah ini justru disambut duka oleh sebagian banyak para pelaku ekonomi sector UMKM. Faktanya, mereka hanya dapat berdagang dalam waktu terbatas dengan jumlah aktivitas konsumen yang terbatas juga. Akhirnya dalam usahanya sehari hanya mendapatkan penghasilan kurang dari 50\% dari penghasilan biasa. Dari penurunan pendapatan tersebut para pedagang sangat gelisah dan kebingungan untuk menjual barang dagagannya dikarenakan semakin berkurangnya jumlah pembeli dimasa PPKM ini.

Terjadinya permasalahan tersebut menjadikan daya Tarik bagi penulis untuk melakukan penelitian yang bertujuan untuk mengetahui sejauh mana dampak dari penyebaran covid-19 ini terhadap perekonomian sektor UMKM di daerah Sukamelang, Subang dan diharapkan dapat memberikan informasi kepada pembaca mengenai dampak dari pandemic ini, sehingga dapat sama-sama untuk mencari solusi atas permasalahan ini.

\section{Metode Penelitian}

Penelitian ini dilakukan di Daerah Sukamelang Kabupaten Subang dengan menggunakan metode pendekatan Deskriptif kualitatif. Data kualitatif merupakan sebuah metode penelitian dengan mengumpulkan data sebanyak-banyaknya untuk membuktikan suatu fenomena yang terjadi. Data kualitatif juga dihasilkan berupa data yang bersifat deskriptif dan naratif yang diperoleh dari pengamatan secara langsung terhadap objek yang diteliti serta hasil wawancara yang dilakukan kepada informan (Suyono, 1985). Menurut (Sugiyono, 2017) Langkah-langkah dalam melakukan analisis data sebagai berikut: 
a. Pengumpulan Data

Pengumpulan data dilakukan dengan cara Observasi, wawancara mendalam, dan dokumentasi. Atau bisa juga dilakukan dengan menggabungkan ketiganya (triangulasi) untuk mengetahui dampak covid-19 terhadap pendapatan para pelaku UMKM.

b. Reduksi Data

Reduksi Data meliputi merangkum, memilih dan memilah hal-hal yang pokok.

c. Penyajian Data

Penyajian data berupa Teks yang bersifat naratif.

d. Penarikan kesimpulan dan Verifikasi.

Adapun sumber data penelitian ini adalah berupa data primer yang dihasilkan dari informan dalam hal ini adalah para pelaku UMKM daerah sukamelang, Subang. Dan data sekunder yang diperoleh melalui kepustakaan, hasil penelitian terdahulu ataupun suatu studi dokumen.

\section{Hasil dan Pembahasan}

Pandemi covid-19 saat ini sedang menjadi perbincangan hangat dikarenakan penyebarannya yang begitu cepat. Apabila dilihat dari peta penyebaranya kasus positif covid-19 ini telah tersebar di 34 provinsi di Indonesia (Withworth, 2020 dalam Harirah, 2020). Penularan virus ini sangat signifikan karena hampir berbagai dunia mengalaminya termasuk Indonesia (Yunus, 2020). Dalam kondisi seperti ini rupanya virus corona tidak dapat dianggap biasa saja. Bukan hanya berpengaruh kepada kesehatan melainkan juga pada kondisi ekonomi Indonesia termasuk pada sector UMKM. Pandemi ini cukup meresahkan Masyarakat, dari mulai kehawatiran atas kesehatan keluarga, pendapatan yang menurun, hasil usaha yang tidak pasti, waktu berdagang terbatas dan masih banyak lagi permasalahan lainnya. Selain itu, para pedagang mengungkapkan bahwa kebutuhan sehari-hari selama PPKM semakin bertambah. Kondisi ini sangat membingungkan bagi pelaku UMKM.

Berikut tabel presentase dampak covid-19 terhadap pendapatan pedagang di sukamelang, Subang.

\begin{tabular}{|l|l|l|}
\hline NO & Jenis Dagangan & \multicolumn{1}{|c|}{ Presentase } \\
\hline 1 & Sayuran & $50 \%$ \\
\hline 2 & Sembako & $50 \%$ \\
\hline 3 & Mainan & $50 \%$ \\
\hline 4 & Pedagang Keliling & $80 \%$ \\
\hline 5 & Makanan Berat & $60 \%$ \\
\hline 6 & Toko Seluler & $80 \%$ \\
\hline 7 & Pedagang Online & $50 \%$ \\
\hline
\end{tabular}




\begin{tabular}{|l|l|l|}
\hline 8 & Pakaian & $50 \%$ \\
\hline 9 & Buah-Buahan & $70 \%$ \\
\hline 10 & Bumbu Masakan & $50 \%$ \\
\hline
\end{tabular}

Sumber data dari hasil wawancara informan

Dari data tersebut dapat dikatehui bahwa dampak dari covid-19 terhadap sektor ekonomi cukup signifikan. Di awali dari pedagang sayuran yang hanya mencapai presentase pendapatan $50 \%$ dari biasanya. Ini disebabkan karena minimnya jumlah pembeli sehingga mengalami penurunan angka pendapatan. Sebagian pedagang sayuran berasumsi bahwa dengan adanya pembatasan kegiatan ini, justru yang semakin ramai adalah pedagang sayuran keliling sehingga masyarakat tidak lagi merasa hawatir dengan berbelanja keluar rumah cukup menunggu pedagang sayuran dirumah saja.

Pedagang sembako, sama halnya dengan pedagang sayuran dari pandemi ini pedagang sembako juga mengalami penurunan pendapatan sebesar 50\%. Memang untuk awal diberlakukan pembatasan para pedagang sembako mendapatkan pendapatan yang cukup tinggi dikarenakan banyaknya masyarakat yang membeli untuk persediaan selama pembatasan diberlakukan. Namun kondisi seperti itu tidk bertahan lama. Semakin lama pembeli kembali menurun dikarenakan pembtasan kegiatan masyarakat diluar rumah. Belum lagi jalan dan pasar yang di tutup membuat masyarakat semakin enggan untuk keluar rumah dan memilih untuk membeli makanan siap saji melalui pelayanan online.

Selanjutnya pedagang mainan. Dalam hal ini adalah pedagang mainan rumahan. Selama pandemi ini para pengrajin mainan juga mengalami penurunan disebabkan kekhawatiran para orang tua untuk melepas anak-anaknya bermain keluar rumah.biasanya anak-anak masyarakat sekitar cukup antusias untuk membeli mainan walaupun hanya sebatas mainan kecil. Namun, dengan pandemi ini anak-anak lebih banyak dirumah dan bermain gadjet untuk meminimalisir penularan covid-19 ini.

Pedagang keliling. Dampak dari pandemi ini ternyata memberikan pengaruh kepada masyarakat untuk hanya di rumah saja sehingga pedagang keliling menjadi salah satu pilihan aman untuk para ibu-ibu berbelanja untuk menghindari keramaian pasar saat berbelanja. Sehingga pedagang keliling mampu mencapai peresentase yang cukup $80 \%$ dari biasanya.

Makanan berat mencapai presentase sebesar $60 \%$. Bagi pedagang makanan berat mencapai presentase $60 \%$ sudang sangat beruntung dibanding tidak sama sekali. Sebagian masyarakat memilih untuk membeli makanan berat yang sudah matang untuk memenuhi kebutuhan selama PPKM. Namun banyak juga yang memilih untuk membeli makanan instan untuk sehari-seharinya. Sehingga pedagang mensiasati penjualan baik secara online ataupun keliling komplek untuk meningkatkan pendapatannya.

Toko Seluler mencapai presentase $80 \%$. Bagi pedagang took seluler besar mungkin suatu keuntungan ketika pandemi ini berlangsung. Karena banyak sekali kegiatan saat ini yang dilakukan secara online sehingga memerlukan kuota sebagai penunjangnya. Namun berbeda dengan toko seluler kecil yang lagi-lagi hanya dapat menunggu kunjungan dari 
pembeli yang semakin menurun. Sehingga tidak sedikit para karyawan toko yang mengajukan pengunduran kerja.

Pedagang Online mencapai presentase 50\%. Dalam hal ini pedagang online hijab. Seiring dengan menurunnya pendapatan ekonomi yang terjadi akibat dampak dari wabah covid-19 ini., maka menyebabkan penurunan pada minat pembelian busana atau pakaian hijab dikarenakan sebagian merasa harus mengatur pengeluaran yang diutamakan untuk pemenuhan kebutuhan pokok terlebih dahulu.

Pakaian mencapai presentase 50\%. Sama halnya dengan pedagang online. Pedagang pakaian pasar cukup gelisah dengan kondisi pandemi. Mereka mengalami penurunan dalam penjualan. Apabila hari-hari biasa dipastikan ada saja pembeli dari mulai pakaian anak, pakaian sekolah, pakaian muslim dan masih banyak lagi. Namun seiring dengan pandemi pembelian semakin menurun.

Buah-buahan mencapai presentase $70 \%$ dalam pandemi ini penjual buah cukup banyak menjual buah-buahannya. Meski tidak sebanyak biasanya namun pedagang buahbuahan mengaku cukup beruntung, diakrenakan ada saja para pembeli buah untuk meningkatkan imun selama pandemi ini.

Bumbu masakan hanya mencapai 50\% sama halnya dengan sayuran, bumbu masakan mengalami penurunan dikarenakan jumlah pembeli yang menurun dan masyarakat yang memilih untuk membeli makanan yang sudah jadi melalui jasa online.

Berdasarkan pemaparan tersebut dapat diketahui bahwa adanya covid-19 ini memberikan dampak yang cukup signifikan terhadap sektor ekonomi UMKM. Diharapkan setelah diberhentikannya PPKM ini para pedagang dapat kembali meningkatkan pendapatannya untuk pemenuhan kebutuhan sehari-hari.

\section{Kesimpulan}

Hasil penelitian dampak covid-19 terhadap kondisi perekonomian sektor UMKM di Sukamelang, Kabupaten Subang adalah besarnya angka penurunan pendapatan para pedagang selama pandemi. Diantaranya, sayuran 50\%, sembako 50\%, mainan anak 50\%, pedagang keliling $80 \%$, makanan berat $60 \%$, toko seluler $80 \%$, pedagang online $50 \%$, pakaian $50 \%$, buah-buahan $50 \%$ dan bumbu masakan $50 \%$. 
Hidzani Asti Rahyuni N dan Izzudin Fuad

\section{Bibliografi}

Asmini, I.N. (2020). Manajemen Business Cycle Sebagai Basis Peluang Usaha Pasca Covid19. Suatu Strategi Pemulihan Ekonomi Masyarakat

Hadiwardoyo, Wibowo. (2020). Kerugian Ekonomi Nasional Akibat Pandemi Covid-19. BASKARA: Journal of Business \& Enterpreneurship, 2(2), 83-92

Hanoatubun, S. (2020). Dampak Covid-19 terhadap Perekonomian Indonesia. EduPhyCouns: Journal of Education, Physchology and Counseling, 2(1), 146-153.

Harirah, Z.,\& Rizaldi, A. (2020). Merespon Nalar Kebijakan Negara dalam Menangani Pandemi Covid-19 di Indonesia. Jurnal Ekonomi dan Kebijakan Publik Indonesia, $7(1)$.

Sugiyono, (2017). Metode Penelitian Kualitatif Untuk Penelitian yang Bersifat : Eksploratif, Enterpretif, Interaktif dan Konstruktif. Bandung: Alfabeta

Yunus, N., \& Rezki, A. (2020). Kebijakan Pemberlakuan Lock Down Sebagai Antisipasi Penyebaran Corona Virus Covid-19. Salam: Jurnal Sosial dan Budaya Syar-I,7(3), 227-238 